December - 2009

\title{
Online and Blended Communities of Inquiry: Exploring the Developmental and Perceptional Differences
}

\author{
Zehra Akyol \\ Suleyman Demirel Universitesi, Turkey \\ D. Randy Garrison \\ University of Calgary, Canada \\ M. Yasar Ozden \\ Middle East Technical University, Turkey
}

\begin{abstract}
This paper discusses findings of a mixed method approach to a study of the development of a community of inquiry in an online and a blended learning environment. A graduate course delivered online and in a blended format was the context of the study. Data were gathered from the Community of Inquiry Survey, transcript analysis of online discussions, and interviews with students and the course instructor. Using multiple qualitative and quantitative data sources, the goal was to explore the developmental differences of the three presences (social, teaching, and cognitive) in the community of inquiry framework and students' perceptions of a community of inquiry. The results indicated that in both the online and blended course a community of inquiry developed and students could sense each presence. However, the findings revealed developmental differences in social and cognitive presence between the two course formats with higher perceptions in the blended course.
\end{abstract}

Keywords: Community of inquiry; online learning; blended learning; social presence, teaching presence; cognitive presence

\section{Instructional Design of Online and Blended Learning}

The increased level of adoption of online and blended learning is forcing educators to put more emphasis on instructional design. Online learning is a method of learning delivered by using asynchronous and synchronous communication technologies; blended learning is the integration of face-to-face and online learning. The definitions sound simple, but in practice it is far from simple to create an online and blended learning environment from an instructional design 
perspective. The quality of these learning environments depends on the design of, and students' engagement in, the learning environment (Duffy \& Kirkley, 2004). Poorly designed learning environments often result in unsuccessful or unsatisfactory educational experiences.

There is a growing emphasis on building learning communities in order to increase student participation and to foster learning in online and blended learning environments (e.g., Rovai, 2002; Palloff \& Pratt, 2005; Barab, Kling, \& Gray, 2004; Conrad, 2005; Colachico, 2007). A community is defined as "a general sense of connection, belonging and comfort that develops over time among members of a group who share purpose and commitment to a common goal” (Conrad, 2005, p.1). It is argued that creating and sustaining a learning community is valuable to enhance student satisfaction and learning through community involvement (Palloff \& Pratt, 2005). Empirical research also confirms the relationship between a sense of community and students' satisfaction and learning (e.g., Rovai, 2002; Ertmer \& Stepich, 2004; Shea, 2006; Shea, Li, \& Pickett, 2006; Liu, Magjuka, Bonk, \& Lee, 2007). However, it is not an easy process to create an effective learning community unless it is planned and opportunities for interaction are built specifically into the online or blended course (Colachico, 2007).

To develop effective learning communities, the community of inquiry (CoI) framework, developed by Garrison, Anderson, and Archer (2000), has generated considerable interest and has been widely adopted and studied by researchers (Garrison \& Arbaugh, 2007; Arbaugh, 2008, Arbaugh, Cleveland-Innes, Diaz et al., 2008). The CoI framework, with its emphasis on critical thinking and collaboration, provides a well-structured model and a set of guidelines to create effective learning communities in online and blended learning environments (Garrison \& Anderson, 2003; Garrison \& Vaughan, 2008).

\section{Community of Inquiry Framework}

The CoI framework is comprised of three interdependent and dynamic structural elements: social presence, cognitive presence, and teaching presence. As shown in Figure 1, the framework assumes that learning occurs within the community through the interaction of these three core elements. The underlying foundational perspective of the framework is a collaborative constructivist view of teaching and learning (Garrison \& Anderson, 2003). Collaborative constructivism is in essence the recognition of the interplay between individual meaning and socially redeeming knowledge; hence, a community of inquiry is a personal and public search for meaning and understanding (Cleveland-Innes, Garrison, \& Kinsel, 2007). A recent study conducted by Shea and Bidjerano (2009) concluded that the epistemic engagement approach, which foregrounds the role of learners as collaborative knowledge builders, is more fully articulated and extended through a community of inquiry. 


\section{Community of Inquiry}

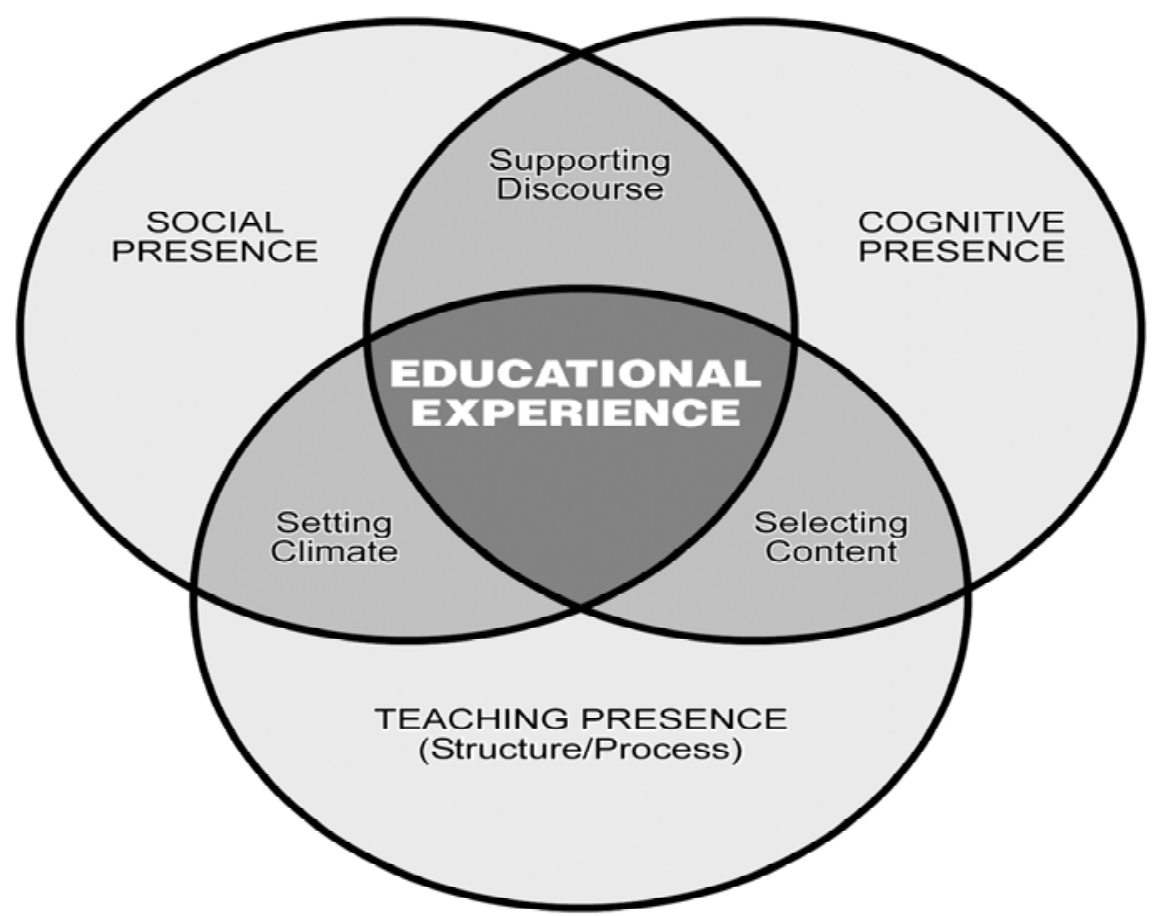

Communication Medium

Figure 1. Community of inquiry framework.

Social presence has been defined recently by Garrison (2009) as "the ability of participants to identify with the community (e.g., course of study), communicate purposefully in a trusting environment, and develop inter-personal relationships by way of projecting their individual personalities” (p. 352). Social presence is an important antecedent to collaboration and critical discourse because it facilitates achieving cognitive objectives by instigating, sustaining, and supporting critical thinking in a community of learners (Garrison \& Anderson, 2003). There are three categories of social presence: affective expression, open communication, and group cohesion. Affective responses are the expression of emotions, humor, and self-disclosure, which support interpersonal relationships. Open and purposeful communication occurs through recognition, encouragment of reflective participation, and interaction. Cohesion and group identification are achieved by addressing participants by name, using salutations, and using inclusive pronouns, such as we and our (Garrison \& Anderson, 2003).

Garrison, Anderson, and Archer (2001) define cognitive presence as "the extent to which the participants in any particular configuration of a community of inquiry are able to construct meaning through sustained communication” (p. 11). Cognitive presence is operationally defined through the practical inquiry model, which consists of four phases: triggering event, exploration, integration, and resolution. The first phase is the initiation of the inquiry process through a problem or dilemma. The exploration phase is the process of understanding the nature of a problem then searching for relevant information and possible explanations. The integration phase 
involves a focused and structured construction of meaning. The final phase is the resolution of a problem by constructing a meaningful framework or by discovering specific solutions. Indicators for each of these categories have been developed to aide in coding for cognitive presence (Garrison \& Anderson, 2003).

Teaching presence is defined as "the design, facilitation and direction of cognitive and social processes for the purpose of realizing personally meaningful and educationally worthwhile learning outcomes” (Anderson, Rourke, Garrison, \& Archer, 2001, p. 5). Teaching presence has a regulatory and mediating role, which brings "all the elements of a community of inquiry together in a balanced and functional relationship congruent with the intended outcomes and the needs and capabilities of the learners" (Garrison \& Anderson, 2003, p. 29). There are three categories of teaching presence: design and organization, facilitating discourse, and direct instruction. Design and organization is the macro-level structure of the learning experience. Facilitating discourse is critical to maintaining students' interest, motivation, and engagement. The third category, direct instruction, is associated with more specific content issues, such as diagnosing misconceptions, injecting knowledge from diverse sources, or summarizing the discussion (Garrison \& Anderson, 2003). By using the term teaching instead of teacher, the possibility of distributing the responsibilities and roles of a teacher among participants is emphasized.

Many research studies have confirmed the three elements of the community of inquiry framework (e.g., Arbaugh, 2007, 2008; Kanuka, Rourke, \& Laflamme, 2007; McKlin, Harmon, Evans, \& Jones, 2001; Meyer, 2003, 2004; Shea, Pickett, \& Pelz, 2003; Shea, 2006; Swan \& Shih, 2005). However, to date, there are few studies that examine the three elements of the framework simultaneously, either qualitatively or quantitatively (Arbaugh, 2007; Garrison \& Arbaugh, 2007). This study examined all three elements of the framework - social, teaching, and cognitive presence - concurrently in two different learning environments (i.e., in an online and a blended course).

The CoI framework is a viable theory both for understanding the dynamics of learning in online and blended learning contexts and for developing effective learning communities. However, there might be external factors affecting the development of each presence, which, in turn, affect the learning experience. Recently, there is growing research examining such external factors as the effect of time (Akyol \& Garrison, 2008), the effect of course duration (Akyol, Vaughan, \& Garrison, in press), and the effect of immediacy-enhancing technologies or rich Internet applications (Ice, Curtis, Phillips, \& Wells, 2007). This study aimed to expand the current knowledge base by examining the impact of course design on the development of CoI elements as well as by illuminating the differences between online and blended learning environments. Knowing how course design might affect social, teaching, and cognitive presence concurrently might help instructors and instructional designers develop appropriate interventions to foster the development of each presence. 


\section{Methodology}

The purpose of this study was to examine the development of a community of inquiry in online and blended learning contexts. More specifically, the aim was to illuminate social, teaching, and cognitive presence differences between online and blended learning contexts. The study applied a mixed methodology approach, which provides a depth and breadth that is not possible using either quantitative or qualitative data exclusively (Creswell, 2003). The context of the study was a graduate course on the topic of blended learning, delivered online in the fall term and in a blended format in the winter term, using asynchronous and synchronous communication technologies (i.e., Blackboard and Elluminate) at a large campus-based research university. At the time of the study, the instructor had offered the course three times in different formats (i.e., face-to-face or online), but each time the course was designed around a community of inquiry approach. In order to articulate a theoretical framework for course redesign, students were introduced to various frameworks including the CoI framework. This situation created an advantage when interviewing the students as they were familiar with the CoI framework and, therefore, better able to understand the interview questions and to provide coherent responses.

Both courses applied a community of inquiry approach. That is, learning activities, strategies, and assessment techniques were developed to reflect social, cognitive, and teaching presence. Hence, the course was exactly the same in both environments in terms of learning activities, strategies, and assessment techniques. The major assignments were article critiques and peer reviews, weekly online discussions (nine weeks of discussion in each course), and prototype course redesign projects. In the first online discussion, the instructor modeled how to facilitate the discussion in an effective way. In order to distribute teaching presence among students and teacher, students were responsible for facilitating and directing the online discussions in each of the remaining weeks.

\section{Participants}

The participants of the study were graduate students enrolled in the course in the fall and winter semesters. The total number of students was 16 in the online course and 12 in the blended course. The demographic data showed that all students were mature in age; in both courses, they were mostly over 30. All students were enrolled in the MA Education program, delivered online. Eight students in the blended course were also enrolled in the MA Education program; four were in different programs or had different status. With regard to their computer skills, fourteen students indicated that they had intermediate computer skills while thirteen had advanced computer skills. Most of the students (12 in the online course, 7 in the blended course) had previous online/blended learning experience, and some of them (8 in the online course) had taken all of their previous courses in online/blended environments. 


\section{Data Collection and Analysis}

Three sources of data were used in this research: transcript analysis, interviews, and the CoI Survey. There were nine weeks of discussion covering the same topics in each course. In order to explore students' cognitive presence, social presence, and teaching presence, the messages that the course instructor or the guest speakers posted were excluded from the analysis. The total number of messages that students posted was 564 in the online course and 439 in the blended course. The unit of analysis was each single message. Transcript analysis was applied to all messages posted by students based on category indicators defined in the CoI framework (Garrison \& Anderson, 2003). The first author and a research assistant analyzed the transcripts by applying a negotiated coding approach (Garrison, Cleveland-Inness, Koole, \& Kappelman, 2006). The researchers coded two discussion transcripts of a previous online course to gain experience and familiarity with the process. In this research, inter-rater reliability was calculated using Holsti's coefficient of reliability (1969), which was .75 for the training session. This provided an estimate of reliability between the coders before the adoption and advantage of a negotiated coding approach. In the negotiated approach, the researchers coded transcripts and then actively discussed their respective codes to arrive at a final assessment of the code. Negotiation provided a means of ongoing training, coding scheme refinement, and controls for simple errors, thereby increasing reliability.

This study included semi-structured interviews with students and unstructured interviews with the course instructor. Eleven voluntary students from the online course and nine voluntary students from the blended course were interviewed at the end of each term in order to gather detailed information about their perceptions of the community of inquiry. The questions focused on how the students sensed and perceived the development of social, teaching, and cognitive presence in the course. Most of the students lived in different cities and were busy, so they preferred to be interviewed during synchronous online meetings. Elluminate was used for this purpose because the students were familiar with it. The other four students (one from the online course and three from the blended course) were interviewed face-to-face. Also, an unstructured interview was conducted with the course instructor three weeks after the blended course ended. During the interview, instructor perceptions of each presence in each course and the themes that emerged from the student interviews were covered. The main emphasis in the interviews was to explore the similarities and differences between the online and blended communities of inquiry. With informed consent, the interviews were recorded and later transcribed. The transcripts of the interviews were analyzed, applying a qualitative content analysis strategy.

The CoI Survey was administered at the end of the class to explore students' perception levels of the CoI presences. The CoI Survey used in this study was developed and validated based on previous studies (Arbaugh et al., 2008). Cronbach's Alpha was 0.94 for teaching presence, 0.91 for social presence, and 0.95 for cognitive presence. The survey included teaching presence perception (13 items), social presence perception (9 items), and cognitive presence perception (12 items). Apart from one student in the online course, all students in both courses completed the survey. 


\section{Results}

\section{Development of a Community of Inquiry}

Using the frequency values of each presence, which emerged from the transcript analysis, a scatter plot was created to illustrate how the community of inquiry as a whole developed in each course. As seen in Figure 2, each element of the CoI developed similarly in both courses. However, detailed comparisons using the frequency values of the categories of each presence indicated differences between the two courses in the development of each presence.

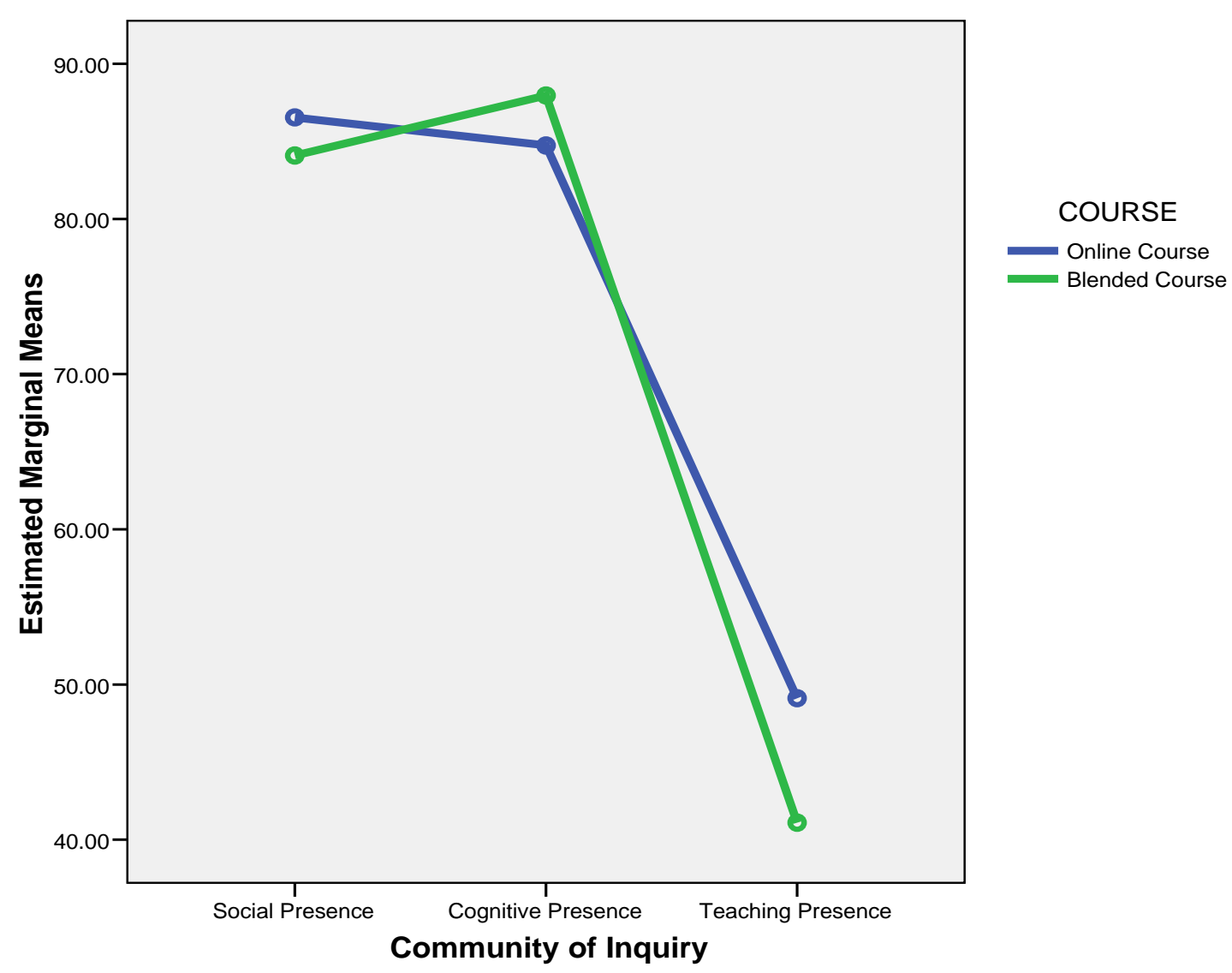

Figure 2. Development of social, cognitive and teaching presence in online and blended course.

\section{Social presence.}

Transcript analysis of online discussions indicated more social presence indicators in the messages posted by online course students, compared to the blended course students (Table 1). In both courses, the majority of the messages were coded as open communication (48\% in online course and $41 \%$ in blended course). As seen in Table 1 , the main differences between the two courses are the following: (i) affective expression was found more in the online course compared 
to the blended course, and (ii) group cohesion indicators were more frequent in the blended course.

Table 1

Comparison of Coding Results for Social Presence between Courses

\begin{tabular}{|c|c|c|c|c|c|c|c|c|}
\hline \multirow{2}{*}{$\begin{array}{l}\text { Social } \\
\text { presence }\end{array}$} & \multicolumn{2}{|c|}{$\begin{array}{l}\text { First } 3 \text { weeks } \\
\text { of discussion }\end{array}$} & \multicolumn{2}{|c|}{$\begin{array}{l}\text { Second } 3 \text { weeks } \\
\text { of discussion }\end{array}$} & \multicolumn{2}{|c|}{$\begin{array}{l}\text { Last } 3 \text { weeks } \\
\text { of discussion }\end{array}$} & \multicolumn{2}{|c|}{ TOTAL } \\
\hline & Online & Blended & Online & Blended & Online & Blended & Online & Blended \\
\hline $\begin{array}{l}\text { Affective } \\
\text { expression }\end{array}$ & $34 \%$ & $17 \%$ & $39 \%$ & $14 \%$ & $25 \%$ & $6 \%$ & $33 \%$ & $12 \%$ \\
\hline $\begin{array}{l}\text { Open } \\
\text { communication }\end{array}$ & $58 \%$ & $36 \%$ & $43 \%$ & $49 \%$ & $43 \%$ & $38 \%$ & $48 \%$ & $41 \%$ \\
\hline $\begin{array}{l}\text { Group } \\
\text { cohesion }\end{array}$ & $7 \%$ & $23 \%$ & $16 \%$ & $22 \%$ & $20 \%$ & $28 \%$ & $14 \%$ & $24 \%$ \\
\hline $\begin{array}{l}\text { No category } \\
\text { detected }\end{array}$ & $0 \%$ & $25 \%$ & $4 \%$ & $16 \%$ & $12 \%$ & $29 \%$ & $5 \%$ & $23 \%$ \\
\hline
\end{tabular}

Further analysis was conducted in order to explore whether these differences were statistically significant. An independent samples t-test was applied with the categories of social presence (affective expression, open communication, and group cohesion) as the dependent variables and the course as the independent variable. The test was significant for the affective expression category $(t(26)=3.757, p=.001)$ and group cohesion category $(t(26)=-3.83, p=.001)$ but not significant for the open communication category $(p=.645)$. Due to the small sample size, MannWhitney $U$ test was also conducted to compare the differences. The results of the test were consistent with the independent samples t-test results, yielding significant differences for affective communication $(p=.002)$ and group cohesion $(p=.003)$ categories between the online and blended courses.

\section{Teaching presence.}

As seen in Table 2, virtually none of the messages in both courses were coded as the design and organization category of teaching presence. On the other hand, online course discussions included more facilitating discourse and direct instruction indicators compared to the blended course discussions. However, these differences were not statistically significant. Neither the independent samples t-test nor the Mann-Whitney $U$ test revealed significant differences between the courses for teaching presence categories. 
Table 2

Comparison of Coding Results for Teaching Presence between Courses

\begin{tabular}{|c|c|c|c|c|c|c|c|c|}
\hline \multirow{2}{*}{$\begin{array}{l}\text { Teaching } \\
\text { presence }\end{array}$} & \multicolumn{2}{|c|}{$\begin{array}{l}\text { First } 3 \text { weeks of } \\
\text { discussion }\end{array}$} & \multicolumn{2}{|c|}{$\begin{array}{l}\text { Second } 3 \text { weeks } \\
\text { of discussion }\end{array}$} & \multicolumn{2}{|c|}{$\begin{array}{l}\text { Last } 3 \text { weeks of } \\
\text { discussion }\end{array}$} & \multicolumn{2}{|c|}{ TOTAL } \\
\hline & Online & Blended & Online & Blended & Online & Blended & Online & Blended \\
\hline $\begin{array}{l}\text { Design and } \\
\text { organization }\end{array}$ & $1 \%$ & $0 \%$ & $1 \%$ & $0 \%$ & $0 \%$ & $0 \%$ & $1 \%$ & $0 \%$ \\
\hline $\begin{array}{l}\text { Facilitating } \\
\text { discourse }\end{array}$ & $28 \%$ & $18 \%$ & $23 \%$ & $23 \%$ & $25 \%$ & $23 \%$ & $25 \%$ & $21 \%$ \\
\hline $\begin{array}{l}\text { Direct instruction } \\
\text { No category }\end{array}$ & $19 \%$ & $19 \%$ & $33 \%$ & $24 \%$ & $38 \%$ & $21 \%$ & $30 \%$ & $21 \%$ \\
\hline detected & $53 \%$ & $63 \%$ & $44 \%$ & $53 \%$ & $38 \%$ & $56 \%$ & $45 \%$ & $57 \%$ \\
\hline
\end{tabular}

\section{Cognitive presence.}

As the distribution of percentages for each category of cognitive presence shows in Table 3, the integration phase was the most frequently coded category of messages posted by students in both courses. Also, integration was found more frequently on the discussion board in the blended course; whereas, exploration was found less frequently on the discussion board in the blended course. The triggering event and resolution phases were low in both courses.

Table 3

Comparison of Coding Results for Cognitive Presence within Three Time Periods

\begin{tabular}{lllllllll}
\hline \multirow{2}{*}{$\begin{array}{l}\text { Cognitive } \\
\text { presence }\end{array}$} & \multicolumn{2}{l}{$\begin{array}{l}\text { First } 3 \text { weeks of } \\
\text { discussion }\end{array}$} & \multicolumn{2}{l}{$\begin{array}{l}\text { Second 3 weeks of } \\
\text { discussion }\end{array}$} & \multicolumn{2}{l}{$\begin{array}{l}\text { Last 3 weeks of } \\
\text { discussion }\end{array}$} & \multicolumn{2}{l}{ TOTAL } \\
& Online & Blended & Online & Blended & Online & Blended & Online & Blended \\
\hline $\begin{array}{l}\text { Triggering } \\
\text { event }\end{array}$ & $15 \%$ & $2 \%$ & $7 \%$ & $5 \%$ & $8 \%$ & $5 \%$ & $10 \%$ & $4 \%$ \\
Exploration & $18 \%$ & $16 \%$ & $30 \%$ & $16 \%$ & $27 \%$ & $10 \%$ & $25 \%$ & $14 \%$ \\
$\begin{array}{l}\text { Integration } \\
\text { Resolution }\end{array}$ & $47 \%$ & $55 \%$ & $45 \%$ & $43 \%$ & $52 \%$ & $57 \%$ & $48 \%$ & $52 \%$ \\
$\begin{array}{l}\text { No category } \\
\text { detected }\end{array}$ & $7 \%$ & $6 \%$ & $10 \%$ & $8 \%$ & $6 \%$ & $4 \%$ & $7 \%$ & $6 \%$ \\
\hline
\end{tabular}

Both the independent samples t-test and Mann-Whitney $U$ test were conducted in order to explore whether there were any statistical differences between the online and blended courses in terms of cognitive presence posting patterns. The results of the independent samples t-test revealed that the exploration $(t(26)=3.125, p=.004)$ and integration $(t(25)=-3.136, p=.004)$ categories were significantly different across the courses. The integration phase was found to be significantly 
higher in the blended course; whereas, the exploration phase was found to be significantly higher in the online course. Mann-Whitney $U$ test results were consistent with the independent t-test results for the categories of exploration $(p=.003)$ and integration $(p=.009)$. However, the MannWhitney $\mathrm{U}$ test also indicated significant differences for the triggering event category $(p=.039)$.

\section{Students’ Perceptions of CoI Presences}

In this section, students' perceptions of social presence, cognitive presence, and teaching presence are presented first by using the CoI Survey and then the interview results. The results of the interview with the course instructor are also presented to provide additional information. The descriptive analysis of survey data shows that students have high perceptions of each presence in both courses (see Table 4). However, the students in the blended course have slightly higher perceptions of all the presences compared to the students in the online course. In order to explore whether the perception differences were statistically significant according to the course design (i.e., online or blended), independent samples t-test and Mann-Whitney $U$ test were conducted. Both test results were consistent, indicating a significant difference only for teaching presence $(t(25)=-2.131, p=.043)$.

Table 4

Students' Perceptions of CoI Elements in both Courses

\begin{tabular}{|c|c|c|c|c|c|c|}
\hline & \multicolumn{2}{|c|}{ Online course } & \multicolumn{4}{|c|}{ Blended course } \\
\hline & $\mathbf{N}$ & Mean & $\begin{array}{l}\text { Std. } \\
\text { Deviation }\end{array}$ & $\mathbf{N}$ & Mean & $\begin{array}{l}\text { Std. } \\
\text { Deviation }\end{array}$ \\
\hline Social presence & 15 & 3.94 & .55 & 12 & 4.30 & .47 \\
\hline Teaching presence & 15 & 4.15 & .51 & 12 & 4.51 & .33 \\
\hline Cognitive presence & 15 & 4.07 & .56 & 12 & 4.31 & .37 \\
\hline
\end{tabular}

The analysis of interviews revealed that students' perceptions of social presence varied in both courses. Although most students expressed that social presence developed in the course, in the online course there were four students who indicated that social presence was high for some of their classmates and low for others. In the blended course, most of the students indicated their satisfaction with the level of social presence. Generally, the students in both courses expressed that social presence created a comfortable environment to share ideas, to express views, and to collaborate. One student from the blended course said the following:

Social presence increases your comfort level when you really speak out and talk. You are more inclined to be sort of honest, straightforward and honestly who you are rather than trying to think about what other people might be thinking of you. You are 
more comfortable and so being more comfortable you definitely want to share more ideas and express viewpoints.

Some students (eight from the online course and three from the blended course) suggested a relationship between class size and social presence. According to the students, social presence was better in small groups. For the students in the online course, the class size was too big for the effective development of social presence. Consistent with this, the students in the blended course were pleased with the class size. They indicated that the small class size decreased the amount of time necessary for the development of social presence. The instructor indicated that generally he could not see a big difference in terms of social presence; however, he did perceive different forms of social presence in each course. He stated that as most of the students in the blended course were new in the graduate program, they were more willing to build social networks and more keen to make friends than some students in the online course who were finishing their degree.

Almost all students in both courses indicated that they perceived cognitive presence to be strong. Three students stated that cognitive presence increased their awareness of their thinking process and helped them to sense progression. According to the instructor, there was also a very high level of cognitive presence in each course. The instructor stated that he was impressed with the level of online discussions and the quality of final papers in both courses. Students' comments about cognitive presence noted the importance of resources and learning activities in order to develop deep approaches to learning in both courses. They found assignments and the final project relevant, challenging, sufficient, and reflective. The instructor also emphasized the role of learning activities. He said "if you do not have the activities that are directed to push students intentionally through four phases of inquiry model, learning does not happen.” Related to the phases of cognitive presence, most of the students in both courses believed that they were able to reach the higher levels, but most of them stated that the resolution phase is achieved individually through their final project. In this regard, one student from the online course said "within the course the students were pretty close to resolution phase but the resolution phase definitely will be cemented when they actually implement course redesign projects." Two students in the blended course also indicated that the triggering and exploration phases occurred during face-toface sessions; whereas, higher levels took place on the discussion board as they had more time to think about the issues. Students in the online class also identified some factors affecting their cognitive presence in the course, such as time needed for discussions.

Students in both courses generally indicated that they found teaching presence high and valuable. However, the students in the blended course seemed to be more aware of their contribution to teaching presence because they shared this responsibility with the course instructor. One student in the blended course stated there was more teacher presence at the beginning but then it quickly evolved into a group teaching presence. He said, "I thought the teaching presence was excellent; it scaffolded nicely, grew and shared by everyone... having that sort of teaching presence impacts the satisfaction tremendously." Similarly, another student said, "I think all of us contributed to the teaching presence, our bringing expertise and insights from our world, so it promotes learning for everyone." With regard to the instructor, the students appreciated frequent communication, 
immediate feedback, availability, good balance between course resources and activities, good facilitation, clarity of assignments and evaluation, correcting misunderstanding, and modeling the use of tools.

Although the students interviewed were generally satisfied with the teaching presence, most of the students from the online course (eight students) and four students from the blended course indicated that they could not see much teaching presence on the discussion board. For the students in the online course, the absence of teaching presence in the weekly discussions resulted in a need for more direct instruction from the instructor; however, this was not the case for the students in the blended course as they had a chance to meet the course instructor every week.

Finally, students' final grades and their participation were also high in both courses. Their final grades were similar: On a 100 point scale, the mean of students' grades were 94.22 in the online course and 98.83 in the blended course. There was no significant difference between the courses in final grades. The attendance rates of the students in the discussions were also high: 92 percent for the online course and 98 percent for the blended course.

\section{Discussion}

The results from the three sources of data (online discussions, survey, and interview data) indicated that each element of a community of inquiry developed successfully in both courses as designed. However, there were developmental differences between the two courses in each presence and their respective categories. In terms of social presence, the transcript analysis revealed differences in the affective communication and group cohesion categories. There was a higher level of affective communication, mostly found as self disclosure, in the online course. This might be due to the need to get to know each other and to set the climate in an online course; whereas, the face-to-face component of the blended course might have decreased the need for affective communication in the online component. The other difference was in the group cohesion category, which was found to be higher in the blended course than in the online course. In the online course, the progression of group cohesion in online discussions throughout the course showed that students started with a low sense of group identity, but their sense of belonging to a group increased steadily over time. Their use of vocatives, inclusive pronouns such as "we," "our," and "us," increased through to the end of the course. Consistent with these results, the analysis of the CoI Survey revealed higher perceptions of social presence in the blended course compared to the online course. Overall these differences suggest that face-to-face interaction might have significant advantages for the development of social presence in the early stages of establishing group identity and trust (Garrison \& Vaughan, 2008; So \& Brush, 2008). Conrad (2005) also found that students valued face-to-face meetings for better connection and that they reported complementary relationships between face-to-face and online communications.

Students in both courses valued social presence. They reported in the interviews that social presence created a comfortable environment to share ideas, to express views, and to collaborate. Therefore, it is critical to ensure an optimal level of social presence, which is a means to greater cognitive presence (Garrison \& Anderson, 2003). Finally, apart from the course design, class size 
was identified as an important factor by the students in both courses. This is consistent with Driver’s (2002) finding that small group size creates higher levels of social presence.

The transcript analysis of online discussions did not reveal a significant difference between the two courses in terms of specific teaching presence categories. However, it was found that the students in the blended course had higher perceptions of teaching presence than the students in the online course. This finding could be anticipated since the students in the blended course had opportunities to interact with the course instructor in face-to-face meetings. The design of both courses provided opportunities for students to share teaching presence by allowing them to lead and facilitate weekly discussions. All the students in the blended course and most of the students in the online course valued this opportunity, indicating that it provided a new way to participate, made the discourse richer with different backgrounds and experiences, and helped them to learn better. The students in the study of Rourke and Anderson (2002) also found peer-led discussions more responsive, more interesting, and more structured compared to instructor-led discussions.

The students in both courses had very positive feelings about the course instructor. However, for students in the online course, there was a need for more direct instruction by the course instructor. Previous studies have also found that students assume teaching presence responsibilities (especially in terms of direct instruction), which are mainly the role of the instructor (Rourke \& Anderson, 2002; Shea et al., 2006). Anderson et al. (2001) and Arbaugh and Hwang (2006) emphasize that the direct instruction category should be implemented by the instructor rather than the students as this category needs subject matter expertise in order to diagnose misconceptions. Perhaps due to the fact that the main medium to interact with the instructor was the online discussion board, they felt more instructional guidance compared to the students in the blended course. It has been found that students need more visible teaching presence of the instructor at the beginning of a course to ease the adjustment process (Cleveland-Innes et al., 2007). Therefore, it is suggested here that a strong and active presence on the part of the instructor - one in which the instructor actively guides the discourse - should take place in the early stages for both a sense of student connectedness and learning (Pawan, Paulus, Yalcin, \& Chang, 2003; Shea, 2006; Ling, 2007).

In both learning environments, the students' level of cognitive presence, as revealed in online discussions, was found to be high, and they perceived cognitive presence to be strong. Contrary to most previous studies (e.g., Garrison et al., 2001; McKlin et al., 2001; Meyer, 2003; Pawan et al., 2003; Vaughan \& Garrison, 2005; Kanuka et al., 2007; Stein et al., 2007), the integration phase was found to be the most active in both online and blended environments. However, the integration phase was found to be significantly higher in the blended course compared to the online course; whereas, the exploration phase was found to be significantly higher in the online course than in the blended course. The explanation for these differences could be that students in the blended course started discussions in face-to-face meetings (i.e., the triggering event and exploration mostly occurred in the face-to-face meetings). In the blended course, online discussion could be more reflective, more rigorous, and easier in terms of tracking ideas. At the same time, some activities associated with exploration, such as brainstorming, might work best face-to-face (Meyer, 2003). Similarly, the students in a study by Vaughan and Garrison (2005) 
indicated that the face-to-face component was the preferred venue for the triggering event and exploration.

Consistent with previous research, the resolution phase was found to have the least activity (McKlin et al., 2001; Meyer, 2003; Pawan et al., 2003; Meyer, 2004; Vaughan \& Garrison, 2005, Stein et al., 2007; Kanuka et al., 2007). However, these findings are explainable in the context of the research reported here and the instructional design of both courses. The explanation offered is that resolution thoughts were directed to the student's individual course redesign project. This was confirmed through the interviews when students stated that they reached resolution by applying solutions to their course redesign projects that were developed in the integration phase. They also identified time as a barrier in online discussions to reaching resolution. Therefore, it may be that the length of the course is not sufficient for students to implement their projects and to share the application results with the other students.

The literature also indicates time, the design of learning activities, and the medium as important factors in reaching higher levels of inquiry (Garrison et al., 2001; McKlin et al., 2002; Meyer, 2003, 2004; Vaughan \& Garrison, 2005; Kanuka et al., 2007; Stein et al., 2007).

The design of learning activities has a significant impact on how students approach learning (Garrison \& Cleveland-Innes, 2005). In this study, students in both courses stressed the role of learning activities in the development of cognitive presence and, in turn, their learning. They described learning activities as challenging, collaborative, and engaging. This study affirms structured collaborative activities for deeper and meaningful learning as suggested previously (Garrison \& Cleveland-Innes, 2005; Schrire, 2006). Moreover, a recent study indicated that epistemic engagement in which the students become collaborative knowledge builders is well articulated and extended through the CoI framework (Shea \& Bidjerano, 2009).

\section{Conclusion}

The main emphasis of the CoI framework is to create an effective learning community that enhances and supports deep approaches to learning. This research explored how a community of inquiry develops in an online and blended learning environment. It is very important to note that both courses were designed using the CoI framework and were equally successful in the development of social, cognitive, and teaching presence. However, due to the small sample size and other variables (e.g., student characteristics, nature of instructional goals, instructor background, learning resources), extreme caution must be exerted in generalizing these findings. Future research studies with larger sample sizes could be undertaken to further examine such external factors. In this research, the information about the face-to-face component of the blended course could only be obtained through interviews. Future research could also investigate the faceto-face component more comprehensively by analyzing face-to-face discussions and interactions. That said, however, taking into consideration such contextual differences and contingencies, the CoI framework shows promise as a tool for designing effective online and blended environments for effective teaching and learning. 
One of the significant contributions of this research is the examination of a community of inquiry in a blended learning environment. The results here also suggest that the blended course has distinct advantages over the online course. An online or blended learning approach will most likely be determined through contextual contingencies, such as the ability or the willingness of participants to meet face-to-face. This study discovered clear strengths of blended learning design, which are as follows: (i) reduces the time needed to develop group cohesion, (ii) promotes reaching higher levels of inquiry by enabling more time for the integration and resolution phases, and (iii) satisfies more students by providing multiple forms of communication. Overall, these findings provide support for the assertion of Garrison and Kanuka (2004) that the blended learning environment is particularly effective in supporting a community of inquiry. 


\section{References}

Akyol, Z., \& Garrison, D. R. (2008). The development of a community of inquiry over time in an online course: Understanding the progression and integration of social, cognitive and teaching presence. Journal of Asynchronous Learning Networks, 12(2-3), 3-23.

Akyol, Z., Vaughan, N., \& Garrison, D.R. (in press). The impact of course duration on the development of a community of inquiry. Interactive Learning Environments.

Anderson, T., Rourke, L., Garrison, D. R., \& Archer, W. (2001). Assessing teaching presence in computer conferencing context. Journal of Asynchronous Learning Networks, 5(2), 1-17.

Arbaugh, J.B. (2007). An empirical verification of the community of inquiry framework. Journal of Asynchronous Learning Networks, 11(1), 73-84.

Arbaugh, J. B. (2008). Does the community of inquiry framework predict outcomes in online MBA courses? The International Review of Research in Open and Distance Learning, 9(2). Retrieved from http://www.irrodl.org/index.php/irrodl/article/view/490/1045.

Arbaugh, J.B., \& Hwang, A. (2006). Does “teaching presence” exist in online MBA courses? The Internet and Higher Education, 9(1), 9-21.

Arbaugh, J.B., Cleveland-Innes, M., Diaz, S.R., Garrison, D.R., Ice, P., Richardson, J.C., \& Swan, K.P. (2008). Developing a community of inquiry instrument: Testing a measure of the community of inquiry framework using a multi-institutional sample. The Internet and Higher Education, 11(3-4), 133-136.

Barab, S. A., Kling, R., \& Gray, J. H. (2004). Introduction. In S. A. Barab, R. Kling \& J. H. Gray (Eds.), Designing for virtual communities in the service of learning (pp. 3-15). New York: Cambridge University Press.

Cleveland-Innes, M., Garrison, D., \& Kinsel, E. (2007). Role adjustment for learners in an online community of inquiry: Identifying the challenges of incoming online learners. International Journal of Web-based Learning and Teaching Technologies, 2(1), 1-16.

Colachico, D. (2007). Developing a sense of community in an online environment. International Journal of Learning, 14(1), 161-165.

Conrad, D. (2005). Building and maintaining community in cohort-based online learning. Journal of Distance Education, 20(1), 1-21.

Creswell, J. W. (2003). Research design: Qualitative, quantitative, and mixed methods approaches. Thousand Oaks, CA: Sage. 
Driver, M. (2002). Exploring student perceptions of group interaction and class satisfaction in the web-enhanced classroom. The Internet and Higher Education, 5(1), 35 - 45.

Duffy, T., \& Kirkley, J. R. (2004). Learner-centered theory and practice in distance education: Cases from higher education. Mahwah, NJ: Lawrence Erlbaum.

Ertmer, P. A., \& Stepich, D. A. (2004). Examining the relationship between higher-order learning and students' perceived sense of community in an online learning environment. Paper presented at the 10th Australian World Wide Web conference, Gold Coast, Australia.

Garrison, D. R. (2009). Communities of inquiry in online learning: Social, teaching and cognitive presence. In C. Howard et al. (Eds.), Encyclopedia of distance and online learning $\left(2^{\text {nd }}\right.$ ed., pp. 352-355). Hershey, PA: IGI Global.

Garrison, D.R., \& Anderson, T. (2003). E-Learning in the 21st century: A framework for research and practice. London: Routledge/Falmer.

Garrison, D.R., \& Arbaugh, J.B. (2007). Researching the community of inquiry framework: Review, issues, and future directions. The Internet and Higher Education, 10(3), 157172.

Garrison, D.R., \& Cleveland-Innes, M. (2005). Facilitating cognitive presence in online learning: Interaction is not enough. The American Journal of Distance Education, 19(3), 133-148.

Garrison, D.R., \& Kanuka, H. (2004). Blended learning: Uncovering its transformative potential in higher education. The Internet and Higher Education, 7(2), 95-105.

Garrison, D. R., \& Vaughan, N. (2008). Blended learning in higher education. San Francisco: Jossey-Bass.

Garrison, D.R., Anderson, T., \& Archer, W. (2000). Critical inquiry in a text-based environment: Computer conferencing in higher education. The Internet and Higher Education, 2(2-3), 87-105.

Garrison, D. R., Anderson, T., Archer, W. (2001). Critical thinking, cognitive presence, and computer conferencing in distance education. American Journal of Distance Education, 15(1).

Garrison, D. R., Cleveland-Innes, M., Koole, M., \& Kappelman, J. (2006). Revisting methodological issues in the analysis of transcripts: Negotiated coding and reliability. The Internet and Higher Education, 9(1), 1-8. 
Holsti, O. R. (1969). Content analysis for the social sciences and humanities. Don Mills: Addison-Wesley Publishing Company.

Ice, P., Curtis, R., Phillips, P., \& Wells, J. (2007). Using asynchronous audio feedback to enhance teaching presence and students' sense of community. Journal of Asynchronous Learning Networks, 11(2), 3-25.

Kanuka, H., Rourke, L., \& Laflamme, E. (2007). The influence of instructional methods on the quality of online discussion. British Journal of Educational Technology, 38(2), 260-271.

Ling, L.H. (2007). Community of inquiry in an online undergraduate information technology course. Journal of Information Technology Education, 6, 153-168.

Liu, X., Magjuka, R.J., Bonk, C.J., \& Lee, S.-H. (2007). Does sense of community matter? An examination of participants' perceptions of building learning communities in online courses. Quarterly Review of Distance Education, 8(1), 9-24.

McKlin, T., Harmon, S.W., Evans, W., \& Jones, MG. (2001). Cognitive presence in web-based learning: A content analysis of students' online discussions. American Journal of Distance Education, 15(1), 7-23.

Meyer, K. (2003). Face-to-face versus threaded discussions: The role of time and higher-order thinking. Journal of Asynchronous Learning Networks, 7(3), 55-65.

Meyer, K. (2004). Evaluating online discussions: Four difference frames of analysis. Journal of Asynchronous Learning Networks, 8(2), 101-114.

Palloff, R. M., \& Pratt, K. (2005). Collaborating online: Learning together in community. San Francisco: Jossey-Bass.

Pawan, F., Paulus, T.M., Yalcin, S. \& Chang, C.F. (2003). Online learning: Patterns of engagement and interaction among in-service teachers. Language Learning and Technology, 7(3), 119-140.

Rourke, L., \& Anderson, T. (2002). Using peer teams to lead online discussion. Journal of Interactive Media in Education, (1). Retrieved from http://wwwjime.open.ac.uk/2002/1/rourke-anderson-02-1.pdf.

Rovai, A.P. (2002). Sense of community, perceived cognitive learning, and persistence in asynchronous learning networks. The Internet and Higher Education, 5(4), 319-332.

Schrire, S. (2006). Knowledge building in asynchronous discussion groups: Going beyond quantitative analysis. Computers \& Education, 46(1), 49-70. 
Shea, P. (2006). A study of students' sense of learning community in online environments. Journal of Asynchronous Learning Networks, 10(1), 35-44.

Shea, P., \& Bidjerano, T. (2009). Community of inquiry as a theoretical framework to foster “epistemic engagement” and "cognitive presence” in online education. Computers \& Education, 52(3), 543-553.

Shea, P., Li, C.S., \& Pickett, A. (2006). A study of teaching presence and student sense of learning community in fully online and web-enhanced college courses. The Internet and Higher Education, 9(3), 175-190.

Shea, P.J., Pickett, A.M., \& Pelz, W.E. (2003). A follow-up investigation of "teaching presence” in the Suny Learning Network. Journal of Asynchronous Learning Networks, 7(2), 61-80.

So, H.-J., \& Brush, T. A. (2008). Student perceptions of collaborative learning, social presence and satisfaction in a blended learning environment: Relationships and critical factors. Computers \& Education, 51(1), 318-336.

Stein, D.S., Wanstreet, C.E., Glazer, H.R., Engle, C.L., Harris, R.T., Johnston, S.M., Simons, M.R., \& Trinko, L.A. (2007). Creating shared understanding through chats in a community of inquiry. The Internet and Higher Education, 10(2), 103-115.

Swan, K., \& Shih, L.F. (2005). On the nature and development of social presence in online course discussions. Journal of Asynchronous Learning Networks, 9(3), 115-136.

Vaughan, N., \& Garrison, D.R. (2005). Creating cognitive presence in a blended faculty development community. Internet and Higher Education, 8(1), 1-12.

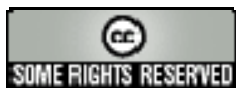

